Тетяна КОВТУН

\title{
ПРО ДЕЯКІ АСПЕКТИ ПЕДАГОГІКИ МИСТЕЦТВА ТА МИСТЕЦТВА ПЕДАГОГІКИ
}

Про новітні освітянські технології в царині гуманітарних знань та необхідність формування новоі системи етико-моральнісних ичінностей. Про мистецтвво як квінтесенцію духовного буття суспільства і педагога мистецтвва як творчу особистість і модератора художницьких послань глядачеві.

Ключові слова: совість, моральність, гуманізм, мистецтво, синергетика, синестезія.

Об инновационных образовательных технологиях в сфере гуманитарных знаний и необходимости формирования новой системы этико-нравственных ценностей.

Об искусстве как квинтэссенщии духовного бытия общества и педагога искусства как творческой личности и модератора художественных посланий зрителю.

Ключевые слова: совесть, нравственность, гуманизм, искусство, синергетика, синестезия.

About innovative educational technologies in the field of human knowledge, and the need for formation of a new system of ethical and moral values.

About art as a quintessence of spiritual being of society, and art tutor as a creative personality and moderator of artistic messages to viewers.

Keywords: conscience, morality, humanism, art, synergetics.

«Мистецтво є естетичною иколою моральності»

О. Герцен

Зміна загальної геополітичної картини світу, процеси глобалізації, коригування ідеологічних векторів всередині країни, прагнення до національної та культурної самоідентичності, критика старих і народження нових міфологем, нарешті, технологічний прогрес та експансія цифрових технологій у медіа-просторі - як позитивна і водночас драматична колізія в формуванні суспільної та індивідуальної свідомості, - все це розмаїття історичного та соціокультурного контенту вимагає відповідного фундаментального переосмислення системи етико-моральнісних цінностей.

Мистецтво є квінтесенцією духовних процесів життя, а «очі художника, то $є$ очі людства» (О. Вайльд). Пізнаючи цінності мистецтва, людина пізнає людське в людині, піднімаючи себе до прекрасного, - так казав великий український педагог-гуманіст Василь Сухомлинський.

Триєдність - художня обдарованість, обдарованість серця і розуму — має складати домінанту мотивації навчання як у спеціалізованих інноваційних закладах для обдарованих дітей, так і в творчих закладах Вищої школи. Саме в гуманітарно-мистецьких співтовариствах напрацьовуються наразі системні синергетичні методики, що базуються на взаємовпливі когнітивних та емоційних факторів у осягненні наукових знань. Мистецтво як таке і педагогіка мистецтва, як модератор авторської творчої думки та комунікатор iï із суспільством, стають надійними спаррінг-партнерами і потребують таких же радикальних іманентних змін і новітніх освітніх технологій. Принцип взаємозв'язку мистецтв формує цілісну художню картину світу, а отже, $є$ методологічним єднаючим принципом змісту багатьох напрямів освіти.

Педагогіка мистецтва охоплює широкий спектр прикладних знань у різних видових напрямках та спрямуваннях наукового засвоєння світу - філософії, культурології, етики, релігії. Ïх змістовне наповнення конкретизоване предметом викладання, вмотивоване формуванням художнього мислення та розвитком креативних здібностей. Багатовимірність сучасних теорій навчання та виховання вимагає визначеності у 
власних національних педагогічних векторах i моделях.

Формула «Творчість як естетика і мораль» могла б стати епіграфом до будь-яких фундаментальних педагогічних ідей сучасної школи. Лише вона спроможна забезпечити умови для формування й розвитку як творчої, так і інтелектуальної еліти Української держави. Ставлячи національну еліту у контекст європейських культур та розглядаючи іiі як синтез рівнів етики культури і системності інтелектуального мислення, ми виділяємо в ній, насамперед, позитивні моральні вартості. Відомо, що криза афінської демократії примусила Сократа поставити питання «що є благо?». Це перше питання аксіології як науки про природу цінностей на теренах ідеї добра.

Ідеї гуманізації є пріоритетними для багатьох світових освітніх систем, одні 3 котрих інтенсивно оновлюються сучасними технологіями, інші зберігають усталені класичні традиції академізму.

Система закритих шкіл-інтернатів сімейної педагогіки Дж. Локка в Англії співіснує з новітніми вищими закладами, де домінують принципи «відкритого» і мобільного навчання.

Освітня концепція «нових матеріальних засобів навчання та виховання» С. Френч у Франції, заперечуючи традиціоналістські шкільні системи, по суті формалізує процес навчання, надаючи провідну роль радикальним організаційним методикам, як то розвиток перцепції, рухової активності та координації шляхом набору текстів у шкільній друкарні.

Поруч 3 низкою «Паблік скулз» - державних шкіл для знедолених - у США активно розвивається концепція освіти «Liberal Art. Liberal Education», коріння якої в ліберальній гуманістичній освіті Стародавніх Греції та Риму, де діти 3 привілейованих прошарків суспільства вивчали так звані artes liberalis — вільні мистецтва (діалектику, риторику, астрономію, музику і латину) і яка покликана формувати духовних і політичних лідерів нової формації.

Досвід загальної американської освітньої системи є доволі продуктивним і активно поширюється в навчальних і наукових закладах гуманістичного напрямку країн слов'янського регіону під назвою «Асоціація Artes liberalis», метою якої є впровадження ідеалів та методів гуманістичної освіти.

Система наукової педагогіки М. Монтесорі, виховуючи загальну почуттєвість (активні, термічні, стереогностичні почуття), опікується також розвитком активної самодисципліни та незалежності в практиці повсякденного життя, вчить будувати кар'єру, прогнозувати свої вчинки та рішення. Останню тенденцію прагматичних підходів до реальності характеризує методика роботи київського ліцею «Гранд» і є безумовно плідною, проте надміру раціоналістичною, інструментально-прикладною, що не залишає зон вільного чуттєвого дихання.

Не можна обминати увагою й Міжнародний альтернативний культурно-освітній рух, що об'єднує 500 шкіл і понад 1000 дитячих садків у Німеччині, Скандинавії, Англії, Японії та Східній Європі, і котрий втілює антропософічні та педагогічні погляди німецького філософа Р. Штайнера - засновника відомої Штутгартської школи. I хоча в системі чимало радикального й на перший погляд неприйнятного (а саме: ведення всіх предметів $з$ першого по восьмий клас одним класним керівником, відсутність директора і надання права управління учительській колегіï), досвід вальдорфської школи перегукується 3 новітніми концепціями української Школи в головному в цүілісному баченні особистості дитини.

На вітчизняній ниві між тим розвиваються інноваційні заклади, котрі готують обдаровану молодь до сповненого драматичних колізій життя як професіоналів мистецтва, сповідуючи передусім духовні засади творчості. Педагогічна парадигма закладу для творчо обдарованих дітей «Київська дитяча Академія мистецтв» містить ідеї надбання студентами не лише знань і вмінь, не лише засвоєння мови мистецтв (театрального, музичного, образотворчого, хореографічного), а й глибоких особистісних переконань, типів поведінки та діяльності. Педагогічний процес в Академіі, механізми його організації грунтуються на розумному поєднанні дисциплін різної спрямованості, єдиному поліхудожньому просторі, що стимулює діяльність як інтелекту, так і психофізіологічного апарату дитини. Працюючи в системі поліхудожнього навчання та ранньої професійно-мистецької орієнтації студентів, педагоги всіх напрямів зорієнтовані на таку методологію викладання, яка б сприяла переходу від перцептивного рівня пізнання до вищих понятійних і творчих рівнів. Урешті-решт прагнуть головного — виховати почуття моральності, примусити працювати душу, повернути дитину до внутрішнього особистого простору, в якому $є$ місце самопізнанню. Суть філософії освіти і філософії виховання в Академії становить принц̧ип калокагатії, поєднання прекрасного і морального.

Ідеї гуманізації освітянського простору є провідними й для інших, спеціально орієнтованих 
вітчизняних закладів середньої ланки. Це Український гуманітарний ліцей, філософією та методологією якого $є$ українознавство як інтегративна система, що поєднує Школу гуманістичного виховання $з$ концепцією успіху; Острозька гімназія, де домінують закони ліберальної гуманістичної освіти, вивчення кількох класичних мов (включаючи латину та давньослов'янську), формування лідерських якостей майбутніх студентів Києво-Могилянської академії.

Моралізаторсько-гуманістична педагогіка Української народної школи, що розвиває ідеї та ідеали родинного виховання і щастя, живиться як принципами народної моралі, так і принципом «живого серця» В. Сухомлинського, засновника Павлиської школи на Кіровоградщині і адепта педагогіки добра і людяності.

До зазначеного типу педагогіки «нового гуманізму», традиції якої започатковані ще Я. Корчаком і збагачуються в гуманітарних закладах України, безумовно близькі гуманістично-особистісні технології Ш. Амонашвілі та школи адаптуючої педагогіки Е. Ямбурга, Б. Бройде (Росія)- тенденція, що засвідчує цілісність і унікальність слов'янського менталітету. Подібний напрям філософії освіти характеризує також: ідеї М. Ліпмана - керівника Інституту з розвитку філософії для дітей (США), котрий закликає від стереотипізації, від мислення блоками «добро-зло» і виховує навички елементарних моральних чеснот та соціальних смислів.

Критичні запозичення розумного творчого та наукового досвіду, як і інтеграція власних, гідних наслідування й поваги, наробок у міжнародні педагогічні та культурологічні системи, є плідною організуючою тенденцією «діалогу культур».

Намагаючись зрозуміти ідеї та принципи функціонування Болонської системи, котру заявлено в перспективних державницьких планах реформування освітньої галузі України, відчуваєш внутрішній опір і бажання захистити те, чим можна було пишатися на теренах вітчизняної науки та мистецтва.

Попри антидемократичні, а часом і репресивні процеси, попри панування ідеологічних кліше i міфологізованої свідомості, радянська та пострадянська системи освіти, література і мистецтво як метанапрями суспільного континууму зберегли себе на рівні дивного феномену — феномену гуманістичності. Гуманістичності як антиподу прагматизмові душі та механістичності мислення. На рівні мистецтва і освіти держава підтримувала високе в людині.
Болонська система 3 iï концепцією внутрішнього відчуження свідомості студента від праці в стабільному колективі, в умовах індивідуального засвоєння науки та індивідуального виживання на ринку праці наразі сприймається як чужа слов'янському менталітетові 3 його відкритістю й безпосередністю спілкування на рівні професіональному і особистісному. Обмін енергетиками на рівні тактильності та живого дискусійного спілкування стає сьогодні відчутним психоемоційним дефіцитом в контексті тотальної поляризації ідеологій і тотального втручання Інтернет-технологій.

Вітчизняною школою педагогіки напрацьовано й творчо запозичено чимало цікавих теорій, котрі чекають на динамічне впровадження в формі конкретних методик в усіх ланках національної освіти. Теорії синестезії, синергетики, сугестології, естетичного універсалізму, наскрізної компаративістики об'єднані власне єдиною холістичною (гармонійно-цілісною) концепцією, котра може забезпечити наукову системність навчання. Проте їх реальна висока вартість може бути забезпечена лише високим рівнем естетизації виховного процесу та етичним рівнем педагогічного середовища. Надмірна інформатизація життя, пов'язана 3 запровадженням комп'ютерних технологій, викликає досить радикальні погляди на комп'ютер, як провокативний інструмент, що по суті скасовує необхідність академічних знань і високої культури. Стандарти сучасної молодіжної субкультури 3 іiі кліповим мисленням, схильністю до клонування моделей життя, вестернізацією ідеалів не завжди рухаються, на жаль, у гуманістичних напрямах. Долаючи опір розбалансованого суспільства, маємо напрацьовувати свої ідеї та ідеали, серед яких чимало майже міфологізованих, але не закреслених часом доброчинностей, - вірності та відданості обов'язку й відповідальності, слова честі ти справи честі.

Гуманістично орієнтовані моделі не заперечують сучасних технологічних реалій, необхідності придбання навичок соціально-громадської поведінки та програмно-раціоналістичної вибудови власного життя. Але вони надають цим прагненням смислу. Лише гуманізуючи особистість ще в сенситивному, найбільш сприятливому для засвоєння етичних та естетичних почуттів віці, можливо домогтися гармонізації душевно-особистісного простору молодої людини, допомогти їй у подоланні бар'єру між знаннями і вчинками на рівні формування совісті. У праці «Психология искусства» Л. Виготський писав і про цю важливу моральну категорію (котрою переймалися найви- 
датніші філософи людства) як про основний закон розвитку внутрішньої культури. Цей закон $\epsilon$ усталеним і незмінним імперативом для кожного митця, бо, як сказав один з експериментаторів театральної режисури В. Мейєрхольд, ми бачимо світ за допомогою окулярів, які носить той чи інший художник.

Вища школа гуманітарних та спеціалізованих творчих напрямів, розвиваючись саме в цьому контексті гармонізації духовних і матеріальних вимірів життєдіяльності, покликана гуманізувати знання, передусім виховувати почуття. Зрозуміло, процес цей неможливий поза власне педагогічним полем і власне мистецтввом педагогіки.

Кожна епоха висуває свої вимоги до педагогіки як науки і до постаті педагога. Для Ж.-Ж. Руссо педагог - охоронець дітей від поганого впливу, для Л. Толстого - приклад для наслідування.

Безцінним на теренах сучасної мистецької освіти України $\epsilon$ теоретичний (як науковців) та практичний (як викладачів) внесок у філософію педагогіки мистецтва та створення нових викладацьких технологій І. Зязюна, Л. Левчук, П. Кононенка, О. Сухомлинської, Т. Рудницької, В. Моляко.

Визначний театральний педагог М. Кнебель у праці «Поезія педагогіки» пише: «В основі педагогічного почуття - жадоба інтересу до людей $<\ldots>$ Найстрашніше виховати ремісника». Про необхідність виховання засобами кіномистецтва таких фундаментальних моральнісно-етичних понять, як духовність, сором, совість, суспільний сором, «втрата яких стає небезпечною хворобою сучасної цивілізації» йдеться в академічних працях професора М. Братерської-Дронь, зокрема, в праці «Інтерпретації наріжних понять моральнісної свідомості в кіномистецтві».

Школа Виховання майстрів кіно, театру, образотворчого мистецтва і виховання власне педагогів мистецтва має домінантні естетичні, психологічні, світоглядні складові: бачити невидимі зорові таємниці та подробиці життя, вміння спостерігати і чути, вміння відбирати матеріал і його монтувати; це відчуття стилю і динаміка емоційної пам'яті, це своєрідна обдарованість до накопичення інтелектуальної інформації на кшталт моделі сучасного тезаурусу, це і готовність до спонтанних актів творчого самовиявлення, коли момент експромту, імпровізації стає результатом найвищого злету педагогічного натхнення.

Кожна яскрава педагогічна постать формуе власні закони спілкування зі студентами, власний стиль «творчої поведінки» (вислів М. Пришвіна), власні естетичні технології. Згадуючи досвід роботи над «Creative dance», визначний танцівник i балетмейстер М. Фокін наводить епізод репетиції «Павільйону Арміді» з великими А. Павловою та В. Ніжинським. Помітивши послаблення інтересу до репетиції, Фокін вдався до вербального жанру, виголосивши цілу промову щодо стилю, перевтілень та інших, власне драматургічних та ідейних елементів балетної вистави.

Модель використання біографій — персоналій видатних людей минулого і сучасного - $€$ блискучою педагогічною знахідкою лекційної діяльності Л. Левчук. В ï науково-мистецтвознавчих інтерпретаціях літопису життя і творчості філософів, письменників, режисерів, історичні постаті наближаються до нас у часі, набуваючи об'ємності живих особистостей. Розважливі інтонації Д. Степовика, його інтелігентна манера і благородна простота оповідей з історії української культури та світового релігієзнавства натхнені внутрішнім темпераментом вченого, залюбленого в мистецтво. Повагою до традицій української театральної Школи позначені телевізійні діалоги О. Вергеліса 3 визначними, а часом i напівзабутими глядачем, митцями національної сцени. Спокійна, психоделічна терапія його голосу гіпнотизує щирістю, делікатністю і теплом людської співучасті.

Замість згаданих монологічних форм спілкування вчених-мистецтвознавців із слухачами діалогічні прийоми співтворчості є звичними в підготовці фахівців творчих професій - акторів, режисерів, телеведучих. Гаряча, запальна енергетика Л. Сердюка - як керівника майстерні кіноактора у КНУТКТ ім. І. Карпенка-Карого, виявляла природно-генетичний код таланту, успадкованого від батька - видатного театрального актора, котрий синтезував традиції школи психологічного переживання і романтичної експресії. Натомість у стилі Сердюка-педагога, як і в його виконавчому акторському стилі (досить згадати роль Данька в постпоетичному фільмі І. Миколайчука «Вавилон XX»), була та особлива медитативно-споглядальна, самоіронічна інтонація, котра характеризує і спосіб національного мислення, і спосіб національного висловлювання, i, власне, орієнтує студентство на пізнання філософії життя і правди почуттів.

Цікавим видається експеримент із введення в навчальну програму підготовки майбутніх кінодраматургів курсу «Майстерність актора», котрий цілком відповідає сучасному дискурсові щодо вироблення системних навчальних методик, котрі базуються на ідеях взаємовпливу когнітив- 
них та емоціогенних факторів, на механізмові співвідношення свідомості студента з об'єктами зовнішнього та внутрішнього сприйняття (так званих ноемах), на емоційно-образному рівні осягнення науки. Ефективним і перспективним для роботи в медійних сферах, що потребують від спеціалістів навичок мистецтва власної публічної репрезентації, $є$ читання курсу «Педагогічна майстерність» на кафедрі кінознавства.

Пасіонарна постать Олександра Довженка як громадянина, художника і педагога кіно поза сумнівом надихала викладацький і режисерський досвід знаних майстрів-педагогів українського кінематографа 1960-90-х рр. - В. Івченка, Т. Левчука, В.Денисенка, Ю. Іллєнка, М. Мащенка. У більшості з них, а також у класиків радянської доби - Л. Кулешова, М. Ромма, С. Герасимова, К. Виноградської - пріоритетне місце посідала виховна парадигма навчання. Виховання творчої особистості. Адже і кінорежисура, і кінодраматургія, що формуються як професії у всеозброєнні універсальних канонічних знань, є професіями насамперед світоглядними. Ремесло, котре за влучним висловом Антоніо Сальєрі, слід класти біля підніжжя всякого мистецтва, в сучасних інтерпретаціях розглядається як сума технологій. Творчий адреналін зазвичай стимулюється «протубераниями серия», якщо переримувати відомий поетичний образ Сонця у Івана Драча. Саме вони, ці «протуберанщі» провокують викиди громадянського темпераменту, і так званого еллану — високої режисерської температури та творчої енергетики.

Класикою української школи кінопедагогіки 3 підготовки режисерів телевізійного кіно стали теоретичні та практичні набутки професорів КНУТКТ ім. І. Карпенка-Карого В. Кісіна та В. Чубасова.

Справжня кінопедагогіка, втім, як і педагогіка театральна, знаходиться в царині духовної творчості, в царині творення особистості. Змістом та метою цієї педагогічної творчості стають внутрішні, іманентні, невидимі для сторонніх процеси рефлексії майбутнього фахівця - самопізнання, саморегуляції, самообмеження, самокритичності, самовимогливості, самоздатності до радикальних рішень, самозреченості - власне самовиховання і самоаналізу. Педагог мистецтва скеровує ці процеси у правильне русло, де не було б місця деструктивізму, самозневірі або самозакоханості. Важливо не прогавити той кризисний момент, коли у художника починають згасати етичні ідеали та «моральнісний закон всередині нас» (I. Кант), коли починається канонізація власних досягнень. Імунітет проти подібних збочень має напрацьовуватися на рівні студентства.

Імунітет цей закріплюється традиціями вузу, естетизацією навчального середовища та гуманізацією навчального процесу, відкритістю і толерантністю міжособистісного спілкування, кліматом вимогливої доброзичливості. Уроки соціожиттєвого та творчого досвіду в Alma mater стають уроками духовної зрілості.

Гіпотетична модель, або професіограма, педагога мистецтва могла б видаватися доволі привабливою, якби ії обов'язковими складовими були творча та наукова обдарованість викладача, патріотичність і розуміння державницьких інтересів, системність мислення і водночас схильність до особистісної рефлексії, талант комунікатора i ритора. «Компенсаційний пакет» педагога чи то «Почесна дотація» - як вид винагороди, встановлений давньогрецьким майстрам пера ще за часів Геродота, міг би слугувати приємним заохоченням цих чеснот. Та справжньою моральною компенсацією для педагога стає момент усвідомлення, що на рівні викладач-студент виховано не лише професіонала, виховано позитивну особистість 3 гідними етичними настановами, гуманістичним типом мислення, з розвиненим почуттєвим апаратом і відчуттям персональної відповідальності за результати власної творчості. Всі ці підходи відповідають концепції актуальних сьогодні загальноцивілізаційних та ліберальних цінностей. 